\title{
The Dreyfus Model of Skill Acquisition: A Career Development Framework for Succession Planning and Management in Academic Libraries
}

\section{Sylvia D. Hall-Ellis and Deborah S. Grealy}

\begin{abstract}
Succession planning and management are critical parts of strategic planning for libraries in the twenty-first century. Making certain that the right people are in place with the prerequisite training and experience to assume leadership positions is a vital part of strategic planning and talent management in libraries that rely on teams of people working in flatter structures and greater accountability. The Dreyfus Model of Skill Acquisition framework suggests that mentoring, coaching, and professional development empower staff for movement up organizational career ladders as part of succession planning and management. To maximize human capital, administrators need to determine skill development levels among staff so that they can identify skill"gaps" internally, create new career ladders, identify emerging stars, and enhance evidence of values for staff contributions.
\end{abstract}

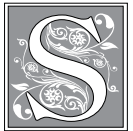

uccession planning allows an organization to anticipate new leadership, assess the skills and knowledge of employees, identify individuals who have leadership potential, and provide professional development opportunities, mentoring, and experiences to prepare the library staff for personnel changes. William Rothwell defined succession planning as anticipating changes in management, creating a strategic plan to identify potential staff members, determining the gaps in their knowledge, and providing training and coaching, special assignments, and experiences so that they are ready to step up when the time comes. ${ }^{1}$ Effective succession planning and management provides a workplace environment ready to respond to sudden changes, critical backups, and individual development. Leadership can be dispersed throughout an empowered highperformance work team with the technical knowledge and experience required to pass on to successors for organizational stability. Established as an area of interest in corporate environments, succession planning became a focus of researchers and practitioners since the 1960s. Paul

Sylvia D. Hall-Ellis is Associate Professor and Interim Director in Westminster Law Library of Sturm College of Law at the University of Denver; e-mail: shellis@du.edu. Deborah S. Grealy is Associate Professor and Associate Dean and Director of the Library and Information Science Program at St. Catherine University; e-mail: dsgrealy@stkate.edu. (C) 2013 Sylvia D. Hall-Ellis and Deborah S. Grealy 
Ostrowski introduced concepts that are commonplace today. ${ }^{2}$ William Mahler and William Wrightnour examined the practices of cultivating leaders within an organization. ${ }^{3}$ Articles focused on the importance of succession planning and management emerged in business literature and addressed the needs in small entities, transportation, health care, family-owned firms, and public utilities. ${ }^{4}$

Libraries face challenges driven by budget cuts, retirements among members of an aging profession, and personnel changes. Succession planning and management are critical parts of strategic planning for libraries in the twenty-first century. Library administrators have to decide how to allocate scarce resources, retrain staff members, reorganize highperformance work teams, and realign workflows. $^{5}$

Library practitioners and scholars paid little attention to succession planning and management until the last decade. Judith Nixon noted that the first article was published in 2004 and highlighted the strategies that a public library in Oregon used to develop a program for preparing and training younger staff members for anticipated promotions to upper-level positions. ${ }^{6}$ In 2005 , Vickie Whitmell identified the issues related to the retirements of a significant number of libraries and information management organizations within the next decade. Practitioners, researchers, and educators discussed the urgent need to take action and ensure that these organizations would provide the education, training, and appropriate work experience for their employees. Members of the Association of Research Libraries (ARL) studied the characteristics needed for leadership within their constituency and prompted leaders to join together and sponsor the Research Library Leadership Fellows (RLLF) Program. ${ }^{7}$ The RLLF program focuses on core strategic challenges facing senior library leaders through a series of on-campus institutes, visits to other campuses, web-based sessions on key issues, and mentoring by ARL member-library directors. A result of the RLLF program is the attention of incumbent directors to devote time and effort to the preparation of their successors.

Librarians in Australia, Canada, and the United Kingdom have studied succession planning and shared their thoughts and strategies to meet the challenge. ${ }^{8}$ Making certain that the right people are in place with the prerequisite training and experience to assume leadership positions is a vital part of strategic planning and talent management in libraries that rely on teams of people working in flatter structures and greater accountability. Given the importance of high performance expected in the academic library environment, administrators need to identify and use strategies that enable them to identify, develop, and retain talented individuals. The Dreyfus Model of Skills Acquisition provides a research-based framework that can be used to monitor the preparation of talented individuals with the technical skills, workplace knowledge, and experience needed for leadership positions.

\section{Human Problem Solving, Production Systems, and Skill Acquisition: The Dreyfus Model}

Brothers Hubert and Stuart Dreyfus developed a model of skill acquisition based on their studies of airplane pilots, chess players, automobile drivers, and adult learners of a second language. They maintained that equating the rules of production systems with skill and expertise did "fundamental violence to the real nature of human intelligence and expertise. ${ }^{\prime 9}$ Based on that contention, they focused their studies on unstructured problems rather than structured areas of decision making in which the "goal and relevant information are clear, effects of decisions are known and verifiable solution can be reasoned out." ${ }^{10}$ Unstructured problems have a potentially unlimited number of possibly relevant facts and features, and the ways the elements interrelate and determine other events are unclear. 
First proposed in 1980, the Dreyfus Model of Skill Acquisition postulates that, when individuals acquire a skill through external instruction, they normally pass through five stages: Novice, Advanced Beginner, Competent, Proficient, and Expert. ${ }^{11}$ Progression through the five stages is viewed as a gradual transition from rigid adherence to rules to an intuitive mode of reasoning that relies heavily on deep tacit understanding with similarities to Donald Schöns theory of "knowingin-action." 12

In the novice stage, the beginner learns objective facts and features relevant to the skill and acquires rules for determining actions based on these facts and figures. Dreyfus and Dreyfus equate the novice stage with their definition of information processing: the "manipulation of unambiguously defined context-free elements by precise rules" (for instance, recognizing the letter $E$ because it has horizontal and vertical lines in a prescribed relationship). Although the novice stage appears similar to the first stage in the information-processing model, Dreyfus and Dreyfus stress that the facts, features, and rules learned by the novice are context-free: "they are so clearly and objectively defined for the novice that they can be recognized without reference to the overall situation in which they occur."13

Learners move beyond the exclusive use of information processing in the advanced-beginner stage as a result of their experience with real situations. Because they begin to perceive similarities with prior situations and events, learners begin to recognize meaningful features and elements in addition to the context-free facts and rules. Competence is developed when learners recognize the relative importance of both situational and context-free features and use the most salient ones to simplify and improve their performances. They organize and develop plans to efficiently and effectively achieve goals.

The competent stage is essentially what cognitive psychologists refer to as problem solving. The fundamental difference between the Dreyfus model and the information-processing model of skill acquisition is seen in the proficient and expert stages. These final two stages of the Dreyfus model are when know-how, "the understanding that effortlessly occurs upon seeing similarities with previous experiences," is acquired..$^{14}$ Therefore, an important assumption of the Dreyfus model is that, with experience and mastery, skill is transformed. Rules and procedures do not simply move to the unconscious level; there is a discontinuity between the competent level and the proficient and expert levels. In fact, as experts pay attention to rules and guidelines that they used as beginners, their performance actually deteriorates. The implication is that formal structural and process models that are integral to systemization and building expert systems cannot fully describe higher levels of expert performance.

\section{Benner's Application of the Dreyfus Model to Professional Education}

Nursing educator Patricia Benner demonstrated that "outcomes of expert practice can be described, and aspects of clinical know-how can be captured by interpretive description of actual practice." 15 In the published findings of her clinical nursing practices study and the subsequent educational programs derived from them, Benner was motivated by the inability of educators and practitioners to adequately describe the scope and depth of nursing as it is actually practiced. Using the Dreyfus Model of Skill Acquisition framework, Benner argued that nurses are not disembodied computers or mechanical monitoring devices that rely on clear explicit signals. Their performance is strongly influenced by the context and meanings inherent in situations. Therefore, the evaluation strategies used by educators and practitioners that relied on context-free principles and elements could not capture the knowledge embedded in the expert's actual practice: 
They [educators and practitioners] assumed that learning and nursing practice could be reduced to a collection of techniques. A technical understanding of nursing was rampant...an assumption that all action can be determined through explicitly stated theories and directives. $^{16}$

Benner considered practice to be more than a collection of techniques defined as "...a socially organized and embedded form of knowledge and ethics" and "an integrated whole that requires the practitioner to develop character, knowledge, and skill in order to contribute to the development of the practice."17 This perspective was uncommon at the time according to cognitive psychologist Sylvia Scribner who pioneered research on work, work practices, and "thinking-in-activity." Scribner defined practice in much the same way as Benner but used the terms "practice" and "activity" interchangeably. She derived her definition from activity theory as it was developed by the Russian psychologist L.S. Vygotsky and suggested that goal-directed actions (or tasks) comprising activities are situated in a context and are impossible to understand without that context. Consequently, activities are the "minimal meaningful contexts for understanding individual actions." 18 Within a group or organization, there can be many activities occurring at the same time, whether separately or in concert, yet they are not isolated from or independent of each other.

The need for further contextualization of learning led to the development of Situated Learning Theory, predicated on Jean Lave and Etienne Wenger's idea of communities of practice wherein people are informally bound together by shared expertise and passion for a joint endeavor. Learning takes place in the same context in which it is applied, becoming a social process through which knowledge is coconstructed by instructors and learners alike as part of professional socialization. ${ }^{19}$
William Sullivan of the Carnegie Foundation for the Advancement of Teaching asserts, "Since professional schools are the portals to professional life, they bear much of the responsibility for the reliable formation in their students of integrity of professional purpose and identity." According to Sullivan, schools must provide ways of creating in students "habits of mind" that define their professional domains. The concept of basic knowledge must expand to include a situational understanding of the moral and social ecology within which those students will practice. ${ }^{20}$

\section{Work Practices of Experienced Reference Librarians}

Bonnie Nardi and Vicki O'Day used activity theory to explore the work practices of experienced reference librarians. They set out to describe how reference librarians working in research libraries at large high-tech companies provided value to their clients and the ways in which they used tacit knowledge as a model for designing intelligent software agents. Unlike researchers who studied librarians with the intent of systemizing or building expert systems, they did not assume that all elements of the information-searching process could be adopted by intelligent software agents, let alone represented by rules. They emphatically stated that machines are not people and people should be treated differently from machines. ${ }^{21}$

...consciousness is not a set of discrete disembodied cognitive actions (decision making, classification, remembering), and certainly it is not the brain; rather, consciousness is located in everyday practice: you are what you do. And what you do is firmly and inextricably embedded in the social matrix of which every person is an organic part. $^{22}$

Nardi and O'Day applied the concept of activity and the multilevel analysis approach described by Scribner to look 
at not only the librarians' actions and how these were carried out but also how they related to the larger social activity in which they were engaged. Specifically, Nardi and O'Day focused on how the librarians participated in the user's activities. They concluded that creating and maintaining a profile of the user-a process of gathering and using information about the user -is at the heart of the reference librarians' work.

A profile contains information about the activity in which the user is engaged that prompted the inquiry and specifications for the search and information about the social and material environment (such as work group members and office resources). Although "profile" is similar in meaning to "reference interview," the authors used it as an inclusive term to emphasize the data-gathering and summarizing aspects of the process to convey how librarians view users engaged in activities rather than a bundle of competencies. ${ }^{23}$

To create these profiles, the librarians conducted subtle and tactful interviews; recognized their users' frustrations; read and understood the relevance of the content of resources; and performed searches based on the kind and quality of information in a resource. None of these actions can be systemized as rules or procedures. Rather than seeing this as a concern, the authors suggest that it is "an opportunity to develop an information ecology that integrates and interconnects clients, human agents and software agents." 24

One concern that the authors expressed was a question that is asked frequently in regard to ethnographic studies: "does the study report a peculiar case of native behavior, or does it generalize to other settings?" 25 Nardi and O'Day addressed this concern by pooling the results of their independent studies, which were concluded at two very similar institutions, and specifically stated that their findings were applicable to corporate libraries; the work of reference librarians in an academic library might look quite different from what they observed. Yet since their study, no one has used a situated activities approach to explore this specific aspect of the work practices of reference intermediaries in any other setting, nor has anyone used it to examine other aspects of practice including the knowledge, skills, and abilities that are used in the searching process.

\section{Technical Skills and Professional Competencies for Academic Librarians}

A plethora of competency and value statements exists in the world of library practice, all designed to offset the perceived failure of library and information studies (LIS) educators to prepare practitioners for the workplace by instilling a standard body of knowledge and requisite skill set for professional-level employees apart from the curricular learning outcomes and objectives of individual schools and programs. In 1999, the American Library Association (ALA) appointed the Task Force on Core Values to address a major recommendation of the First Congress on Professional Education to clarify the core values of the profession. ${ }^{26}$ Academic and research libraries have not identified a uniform set of competencies. The competency statements and behavioral norms affecting practitioners in academic communities tend to be highly specific in nature.

A central issue to be discussed within institutions and professionwide is what should be considered core competencies. This fundamental question-what constitutes the collective knowledge unique to this profession and these institutions that adds value to the services provided to users - is the strategic key to the choices that must be made. The answer to this question is what will allow academic libraries to remain viable.... ${ }^{27}$

Jurow cites Dorothy Leonard-Barton, ${ }^{28}$ saying that core competencies - however 
defined-necessarily extend beyond the knowledge and skills of employees, and include the ways in which work gets done in the organization through technical and managerial systems and culture.

The Special Library Association (SLA) was the first library organization to define a set of core personal and professional competencies for its members' practice. ${ }^{29}$ The set of core personal and professional competencies "form the basis for the continued survival and growth of special librarianship in the information age." The first set of competencies for the library profession, they are equally adaptive for other information settings, especially those in academe. Librarians who have internalized the skills and competencies outlined in the SLA document find themselves uniquely prepared to step into leadership roles in any type of library. The personal and professional competencies can be broadly categorized under five general headings: vision, service, networking, professional growth, and political awareness. ${ }^{30}$

The tripartite education of students who seek careers as academic librarians begins in an LIS graduate program. The stages of professional growth and development begin with formal graduate coursework, extend through on-the-job training, and continue through work experiences and professional development experiences throughout a career. New information professionals earn library degrees and leave graduate school ready to launch their careers. Successful graduates have an appreciation for librarianship as discipline that is based on collective, cumulative research and education. They are vitally connected to practice, socially organized into the profession, and embedded with knowledge and ethics. Practitioners and educators recognize the fact that LIS education provides an array of core competencies designed to last an entire career. ${ }^{31}$ As with professional education in law, medicine, accountancy, and social work, library school studies serve as the basic foundation for a successful, multidecade career.

Sandy Hirsh suggests that, when students attend LIS graduate schools with curricula that are focused on competencies, new librarians are able to demonstrate their mastery of the knowledge and skills that employers seek when making hiring and promotion decisions. ${ }^{32}$ Therefore, the individual librarian, the immediate supervisor, and the administrator are responsible for determining the strategies that will be available within the organization to enable employees to enhance their skills, learn new techniques, increase professional knowledge, and prepare for promotion to leadership positions.

Library leaders use lists of competencies to assess the skills, knowledge, experience, and abilities of current and future employees. ${ }^{33}$ To better identify the competencies required of library leaders, the Special Libraries Association developed a list of competencies in an attempt to provide common language to guide leadership development. The Library Leadership Administration and Management Association ${ }^{34}$ and other specialized library associations followed suit by articulating their core competencies and values. These include (but are not limited to) the American Association of Law Libraries, the Association of College and Research Libraries, Art Libraries Society, and ALA's Government Documents Round Table.

\section{Applying the Dreyfus Model for Skills Acquisition in Academic Libraries}

Considered concurrently, the perspectives on learning posited by Dreyfus, Benner, Scribner, Lave and Wenger, Sullivan, Nardi and O'Day, and Hirsh suggest that librarianship is a profession that an individual enters through graduate LIS education. As a novice, an individual becomes a member of the community of practice and assumes personal responsibility for learning and mastering technical skills and competencies through experi- 
ence, mentoring, professional development, and continued actions (or tasks) comprising activities situated in a library or information environment.

The actions that constitute work as an academic librarian are consciously undertaken and targeted at specific goals that may or may not be explicitly directed toward the object of the activity but are nonetheless directed and guided by it. These actions have operational aspects that are determined by the conditions under which they are carried out. Considered part of the beginner and advanced-beginner stages of the Dreyfus Model of Skill Acquisition, routine tasks for academic librarians are the unconscious abilities that emerge as a result of practice and experience, such as searching databases or the Internet with key words and commands or writing bibliographic citations. If conditions change to where the normal execution of an operation is impeded, conscious attention is necessary and the operation becomes an action.

Analyzing actions (tasks) and operations provides a description of a set of procedural steps that provides a partial understanding of what is occurring because it assumes that they are undertaken as ends in themselves. This analysis fails to consider not only the relationship between the actions and the larger community of practice activity of which they are a part, but also the overall nature of the activity. Academic librarians can use observations and experiments to identify and describe qualitative differences between the processes of experienced workers and those of novices.

Understanding how experienced librarians use knowledge to get around in the library environment and how and what knowledge was acquired in the course of getting around illustrates the ways in which an individual gains mastery over technical skills, increases proficiencies and competencies, and progresses professionally. These enhancements to the skills levels at the time of LIS graduation give evidence of readiness to move up a career ladder and preparation for the assumption of leadership assignments. Readiness for leadership is a fundamental component of succession planning and management. Those individuals who work over time to increase their technical skills and competencies, coupled with tacit knowledge of the organization, become prime candidates who will be prepared to take leadership roles.

\section{Academic Librarians as Adult Learners}

A customer service orientation and ongoing training maintain value for academic librarians. Technologies in which scientific principles are put to practical use provide a strategic advantage to individuals and the organization. The value of a person is directly measurable in terms of how that individual leverages organizational knowledge and contributes to the organization's competitive edge. Senge and Drucker emphasize that knowledge is perhaps the single most meaningful resource today ${ }^{35}$ Competition in the marketplace takes place on a global scale. As an adult learner, the information professional acquires technical skills and achieves competencies that are applied to professional education in librarianship.

In addition to their long-standing roles as organizers and mediators of library services, academic librarians train information seekers, participate with faculty colleagues to discover digital assets and build scholarly communication repositories, and mentor aspiring new professionals. In the last decade, dramatic changes have occurred in the ways that information is acquired, described, accessed, packaged, and delivered to an increasingly diverse clientele. Environmental changes in user demographics, their needs and expectations, and technological capabilities converge in a turbulent environment that can be navigated through ongoing individual and organizational learning. The librarians' traditional responsibilities are in flux as organizational charts are rearranged 
and hierarchies are leveled. Traditional job distinctions are giving way to an ambiguous process orientation. Such shifts disrupt the librarians' abilities to meet user needs and expectations and affect the morale of the library workforce. Nowhere is this shift more apparent than in the front-line, public service sectors of academic libraries.

Although traditionally oriented to curricular support and research, academic libraries are subject to technological pressures. With the increasingly competitive stance of American higher education, academic librarians are responding to the changing demands and expectations from new generations of students and faculty. Twenty-first century postsecondary students are customers and clients; the traditional teaching and research mission of the academic librarian has new complexity in an increasingly digital environment. "Employees of college and university libraries can rarely afford the luxury of indulging in comfortable learning curves. Regular demands on services continue, while the internal rhythm of the academic calendar allows little downtime." ${ }^{36}$

\section{Applying the Dreyfus Model for Skills Acquisition to Changing Demands}

The twenty-first century academic library is a vibrant place of change, discovery, learning, and experimentation, relying on the Library as Place, aggregated serials, open access, and digital repositories, a range of technology services, tutoring and learning services, advising, and other services aimed at meeting the needs of students and scholars. ${ }^{37}$ These differentiated skills can be seen in the work of reference librarians, cataloging and metadata specialists, and administrators in the academic library environment.

Training and learning throughout a professional career is not routine or repetitive. Professional development opportunities focus on specific forums for personal growth in support of organizational change. The recrafting of position descriptions when new employees will be hired or during a major reorganization in response to a fluid workplace and flattening organizational models reflect skills and competencies rather than same old tasks. Updating position descriptions enables managers to incorporate expectations that staff grow and develop professionally so that increasingly sophisticated user demands can be met.

Position descriptions are generally prepared by library managers in consultation with human resources officers. While the goal is to craft a position description that meets an organizational need, they work within the constraints of previous descriptions and legally acceptable language. Writing job descriptions does not lend itself to the recognition of nuanced levels of skills development or the relationship between tacit understanding and ability. The focus is on the cognitive abilities and explicit skills needed to do the work. Position descriptions use verbs reflecting levels of skill tied to educational preparation, years of experience, and salary.

Aligning skill levels with career ladders enables both the employee and the manager to identify the development of competencies that parallel advancements through positions from entry-level to mastery to expert. Succession planning and management in academic libraries depend on the movement of talented individuals up a career ladder to prepare them for leadership in departments, divisions, and the organization.

\section{Preparing for Career Advancement and Promotion}

To follow a career trajectory, individual librarians need to take charge of their learning. As knowledge-workers in a profession driven by technological change, academic librarians possess the education that equips them with the theoretical framework, core competencies, and technical skills for a fluid work environment and ongoing professional development. ${ }^{38}$ After graduation, novice academic librarians are encouraged by 
their peers to see that education "should no longer be seen as a process of transmitting what is known, but as a lifelong process of continuing inquiry." 39

Adult learning can be described as voluntary, practical, and skill-oriented rather than as academic. ${ }^{40}$ Malcolm Knowles provides a practical, applied way of engaging learners outside traditional classrooms by allowing motivated adults to profit by and build from their own unique experiences and strengths. This approach involves a fundamental shift from instructor-centered to learnercentered education. The critical function of the instructor is to guide interactions and create a learning environment from which participants can extract and maximize learning. Learning becomes a cooperative venture whose chief purpose is to help the individual discover the meaning of the experience. This fundamental shift has significant implications for education in the information age, a characteristic of which is the emphasis on continual learning and personal development.

Academic librarians can take charge of their education as self-directing activities with deep psychological needs to be seen in the same way by others when they deliberately embark on the most important learning of all: "learning how to learn" and mastering the skills of selfdirected inquiry. Following a process of self-evaluation, they can measure gains in competence, rediagnose competence levels, and enter a new cycle of learning. As they make these advancements and hone their competencies, academic librarians move through the stages in the Dreyfus model. Consequently, they become candidates for leadership as part of the institutional plan for succession planning and management.

Degree aspirations among adult learners are powered by the pursuit of a promotion or career change, the desire to meet new persons, to read more widely, or to explore new ideas and interests. ${ }^{41}$ Librarians can seek new job opportunities or a promotion within the organization.
An individual's professional success is affected by the degree to which learning is experience based and problem centered and the extent to which it can be integrated into the learning process to improve personal abilities to cope with life problems. ${ }^{42}$ Librarians who embrace lifelong learning in their personal lives and careers will seek, hold, and thrive in such an environment.

Providing opportunities for professional development, mentoring, and coaching new hires empower every staff member to prepare for movement up organizational career ladders. Each staff member benefits from guidance and mentoring to prepare for advancement. To maximize human capital, supervisors, managers, and administrators need to determine skill development levels among staff so that they can identify skill "gaps" and talented individuals. By hosting or sponsoring staff development and training sessions, the library recognizes the importance of its role as a learning organization. Individuals with specific interests and talents can be selected and supported as they move from one level to the next. They can fill "gaps" internally, create new career ladders, identify emerging stars, and enhance evidence of values for staff contributions.

\section{Study Methodology}

To determine the competencies that academic librarians in reference, cataloging and metadata services, and administration would need to be promoted, the researchers wanted to identify the skills that reflected higher-level duties and responsibilities. In these ever-changing times, the Dreyfus model has applicability to determine the scaffolding up of library workplace competencies.

To perform a systematic, objective explanation of the position announcements for academics, the researchers employed a descriptive content analysis methodology. ${ }^{43}$ This study documents the content analysis for 9,500 academic librarian position announcements posted from 
TABLE 1

Position Descriptions, Education, and Experience Levels

\begin{tabular}{|l|l|l|}
\hline Position Level & Education & Experience \\
\hline Entry-level & MLIS & None to 2 years \\
\hline Experienced & MLIS and second graduate degree & 2 to 4 years \\
\hline Department Manager & MLIS and second graduate degree & 5 to 7 years \\
\hline Chief Administrator & $\begin{array}{l}\text { MLIS and second graduate degree } \\
\text { (prefer doctorate) }\end{array}$ & 8 or more years \\
\hline
\end{tabular}

1998 through 2010 in American Libraries, Library Journal, ALA Jobline, the Mountain Plains Library Association Jobline, LibGig, and the Colorado State Library Jobline. For the purposes of this study, positions were grouped by the employers' divisions based on years of experience (see table 1).

For each job announcement, the specific descriptors identified academic preparation, required qualifications, preferred competencies and skills, primary work assignment functions, institutional information, and specific resources available through websites and hyperlinks. Conducting a descriptive content analysis enabled the researchers to describe substance and form characteristics examined in the position announcements and to make inferences to the community of librarian practitioners. Given the researchers' decision to use content analysis as a quantitative message analysis methodology, they relied on the scientific method, including attention to objectivity/intersubjectivity, a priori design, reliability, validity, generalizability, replicability, and hypothesis testing so that the types of variables that could be measured or the contexts in which the position descriptions were created would not be limited. ${ }^{44}$ Consequently, conclusions were limited to the descriptive nature of the competencies listed in the position announcements.

The format and structure of position descriptions were identified, measured, and analyzed at the clause level. Methodologically speaking, the word, the sentence, the paragraph, and the entirety of position announcements were rejected. The clause was the smallest identifiable unit that could be coded for the desired variables and provided maximal variance across the individual announcements. Because the study under discussion did not replicate an earlier investigation, the researchers had to develop the measures. Therefore, the issue of validation began de novo. ${ }^{4}$

The researchers constructed a coding scheme that consisted of a set of actual, concrete measures in a codebook for each major grouping of positions: reference, cataloging and metadata, and administration. The categories in the codebook included an appropriate code for each data unit. Variables identified at the clause level were broken down into separate measures to avoid the potential convergence of multiple measures. Detailed instructions included in the codebook provide sufficient specificity to avoid ambiguity and confusion as well as coding protocol guidelines. The project codebook included operational definitions for each variable and the form used to code each position announcement. Based on Stevens' classic levels of measurement, the researchers decided to use an interval scale. ${ }^{46}$ Each variable was assigned a rank order scale that corresponded to the stated level of complexity. Measures were assigned in accordance with the key standards of reliability, validity, accuracy, and precision.

After identifying position descriptions for the first year (September 2000 through August 2001), the researchers conducted practice coding to test the 
scheme's reliability and viability. Minor adjustments resulted, including the further differentiation among major work responsibilities, the elimination of anticipated variables not present in the data set, and the collapse of variables into a single category in cases that did not merit subcategorization.

Following these modifications, the researchers grouped variables so that they could be combined mathematically into a single indicator. The researchers used the modified codebook to code the data manually for the position descriptions. A researcher and an assistant coded the data independently to ensure consistency and reliability throughout the coding process. The coded scores reflected high agreement and variation. Using Holsti's method $\left(\mathrm{PA}_{\mathrm{o}}=2 \mathrm{~A} / \mathrm{n}_{\mathrm{A}}+\right.$ $\mathrm{n}_{\mathrm{B}}$ ), the researcher calculated a reliability coefficient of 0.91 . $^{47}$

Data gathered during this study were stratified by type of position and segregated into six major categories for analysis: general description of the potential employer and expectations of employees; academic preparation, including additional graduate degrees; technical skills and competencies; related tasks; assignments outside the primary work domain; and communication, language proficiencies, and interpersonal working competencies. Each category included data as represented by specific variables in the project codebook.

The current study focuses on technical skills and competencies. Using the nuances of the statements within the articulation of competencies and correlating these data with the years of experience and education, the researchers determined its placement within the Dreyfus framework (see table 2). This process suggests that there are specific levels of skills acquisition and mastery that are essential for advancement within the ranks of academic librarians.

\begin{tabular}{|c|c|c|c|c|c|}
\hline \multicolumn{6}{|c|}{$\begin{array}{c}\text { TABLE } 2 \\
\begin{array}{c}\text { Dreyfus Model of Stages of Skill Acquisition, Scaffolded Knowledge, } \\
\text { and Competencies }\end{array}\end{array}$} \\
\hline $\begin{array}{c}\text { Skill } \\
\text { Level }\end{array}$ & Assessment & $\begin{array}{c}\text { Decision- } \\
\text { Making }\end{array}$ & $\begin{array}{l}\text { Competencies: } \\
\text { Reference } \\
\text { Librarians }\end{array}$ & $\begin{array}{l}\text { Competencies: } \\
\text { Catalogers } \\
\text { \& Metadata } \\
\text { Specialists }\end{array}$ & $\begin{array}{l}\text { Competencies: } \\
\text { Library } \\
\text { Administrators }\end{array}$ \\
\hline Novice & \multirow{3}{*}{ Analytically } & \multirow{3}{*}{ Rational } & $\begin{array}{l}* \text { familiarity } \\
* \text { ability } \\
* \text { recognize }\end{array}$ & $\begin{array}{l}* \text { perform } \\
* \text { awareness } \\
* \text { familiarity }\end{array}$ & $\begin{array}{l}* \text { recognize } \\
* \text { appreciate } \\
* \text { understand }\end{array}$ \\
\hline $\begin{array}{l}\text { Advanced } \\
\text { Beginner }\end{array}$ & & & $\begin{array}{l}* \text { participate } \\
* \text { provide } \\
* \text { assist }\end{array}$ & $\begin{array}{l}* \text { draft } \\
* \text { use } \\
* \text { experience }\end{array}$ & $\begin{array}{l}* \text { participate } \\
* \text { supervise } \\
* \text { assist } \\
* \text { monitor }\end{array}$ \\
\hline $\begin{array}{l}\text { Compe- } \\
\text { tent }\end{array}$ & & & $\begin{array}{l}* \text { coordinate } \\
* \text { demonstrate } \\
* \text { oversee } \\
* \text { knowledge }\end{array}$ & $\begin{array}{l}* \text { complete } \\
* \text { knowledge }\end{array}$ & $\begin{array}{l}* \text { plan } \\
* \text { manage } \\
* \text { develop }\end{array}$ \\
\hline Proficient & \multirow{2}{*}{ Holistically } & $\begin{array}{l}\text { Intuitive/ } \\
\text { Rational }\end{array}$ & $\begin{array}{l}* \text { supervise } \\
* \text { direct }\end{array}$ & $\begin{array}{l}\text { * review } \\
* \text { train } \\
* \text { supervise }\end{array}$ & $\begin{array}{l}* \text { design } \\
* \text { supervise } \\
* \text { prepare }\end{array}$ \\
\hline Expert & & $\begin{array}{l}\text { Intuitive } \\
\text { (Arational) }\end{array}$ & $\begin{array}{l}* \text { work } \\
* \text { conduct }\end{array}$ & $*$ master & $\begin{array}{l}* \text { collaborate } \\
* \text { develop } \\
* \text { represent }\end{array}$ \\
\hline
\end{tabular}




\section{Observations \& Conclusions}

Grounded theory is a research methodology in which theoretical construct emerges from the richness of the data. Independently created position descriptions, when collected and analyzed, constitute a rich data set. Considered alongside the Dreyfus model, these data reveal natural stratification with regard to education, years of work experience, and salary (see table 3). The data further reveal trends that may lead to the development of hypotheses and guiding principles and, with further study, emerge as theoretical underpinnings of librarianship. The Dreyfus model is an example of scaffolded learning and increasing skill development throughout a career. Position descriptions provide snapshots along the continuum providing a critical mass of data whose richness allows grounded theory to emerge.

A review of position descriptions against the Dreyfus Model of Skill Acquisition framework results in five emergent theories. Emergent theory \#1 suggests that graduate library education focuses on learning outcomes and a competencybased education movement with welldefined behavioral objectives - within the context of the ALA standards for accreditation - and institutional process for development and modification.

Emergent theory \#2 reveals that work in academic libraries is far more complex than most formal theories predict because of high levels of judgment, knowledge, and ethical behavior. Major aspects of the work cannot be captured in formal descriptions of processes and techniques. Based on studying and practice situation to determine level of practice, librarianship elucidates strengths rather than deficits and describes practice capacities rather than traits or talents.

Emergent theory \#3 recognizes that graduate library education moves individuals from novice to advanced beginner. The combination of formal courses, hands-on labs, projects (service learning and community engagement), intern- ships, and practica provide the library studies experience and socialization into the profession.

Emergent theory \#4 reveals that employers are responsible for creating and maintaining learning environments for all staff. It is the responsibility of library managers and supervisors to move employees from advanced beginner to competent. These activities are resource dependent, requiring significant investments of time, money, and personnel. Employees who are skilled in mentoring and coaching require time to move their colleagues from competent to proficient and expert.

Emergent theory \#5 suggests that the Dreyfus model has applicability for libraries as learning organizations. The application of the Dreyfus model has potential for use in talent management and retention for current staff, the recruitment of new hires, and effective succession and management planning.

Succession planning and management provide a deliberate strategy to identify, develop, retain, and reassign personnel in anticipation of changes in the library staff. Retaining talented individuals is a key to creating a motivated, productive high-performing work team. Identifying and developing individuals so that they can grow professionally heightens their loyalty to the library organization and encourages them to seek opportunities that lead to promotions. Library managers and administrators are responsible for identifying the skills and competencies that are required for upward movement on a career ladder. The Dreyfus Model provides a framework to track the increasing level of competencies and scaffolded difficulties of the tasks. Through a comprehensive professional development and talent management plan, the library administrator can empower employees to take an active role in their learning and growth so that when advancement and promotion is possible, they are ready to meet the challenge. 


\begin{tabular}{|c|c|c|c|}
\hline \multirow{7}{*}{ 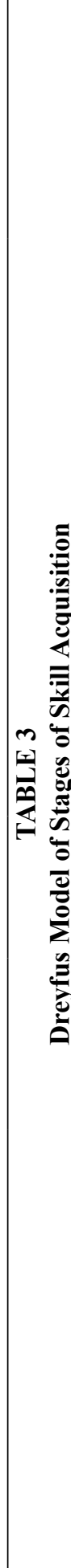 } & 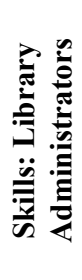 & 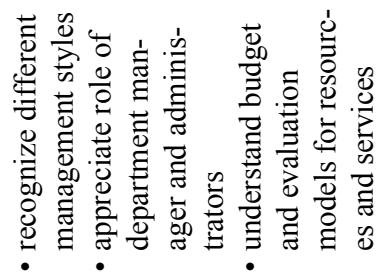 & 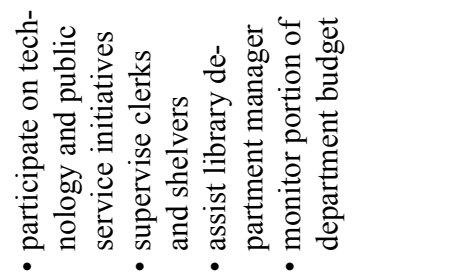 \\
\hline & 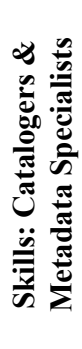 & 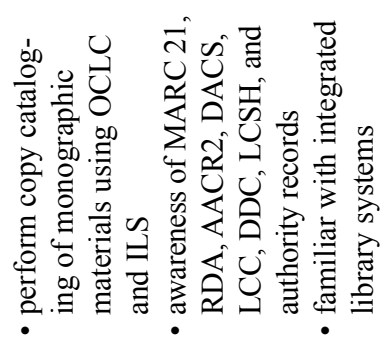 & 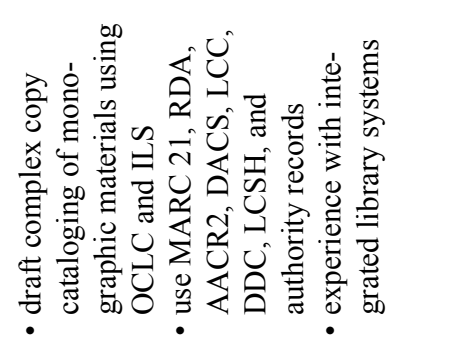 \\
\hline & 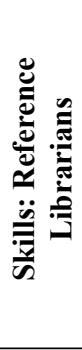 & 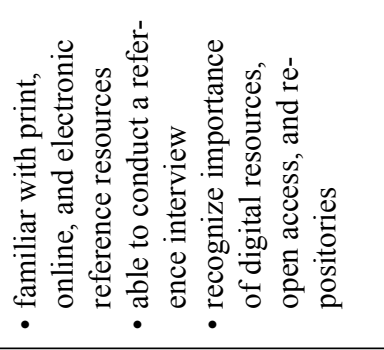 & 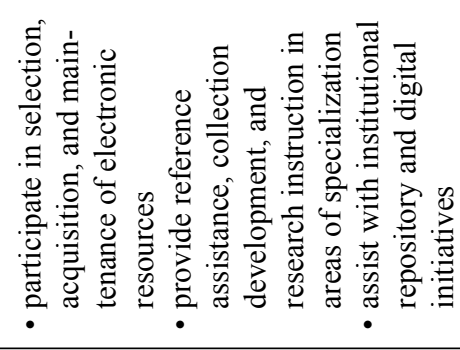 \\
\hline & 竞 & & 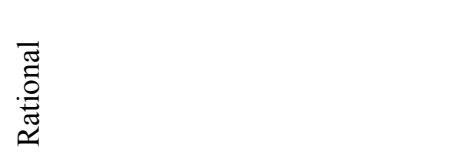 \\
\hline & 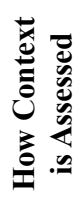 & & 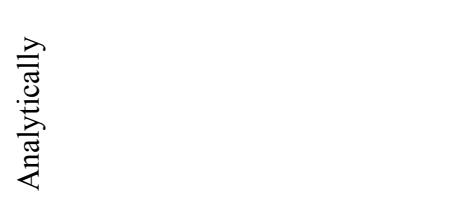 \\
\hline & 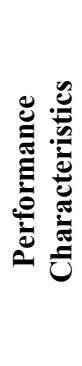 & 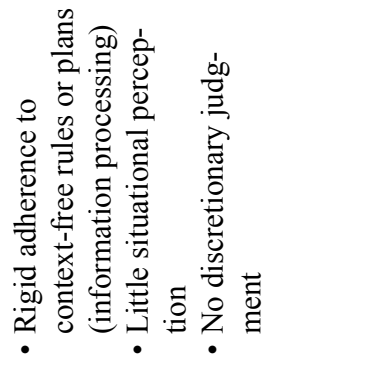 & 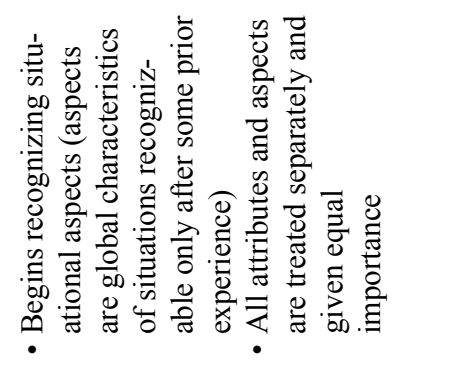 \\
\hline & 竞 & $\begin{array}{l}8 \\
.0 \\
z \\
z\end{array}$ & 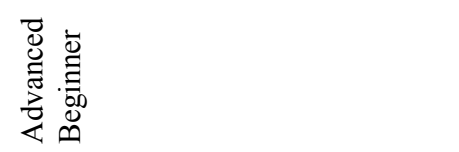 \\
\hline
\end{tabular}




\begin{tabular}{|c|c|c|}
\hline \multirow{7}{*}{$m \frac{\Sigma}{\infty}$} & 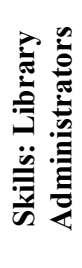 & 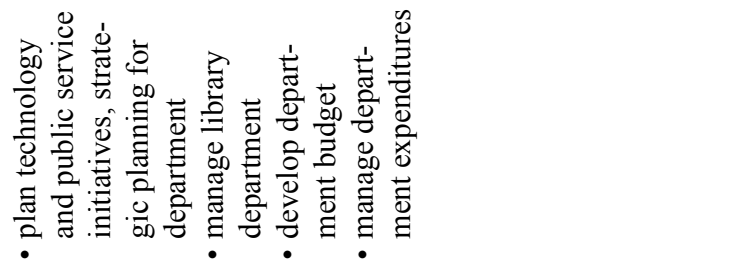 \\
\hline & 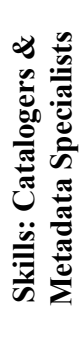 & 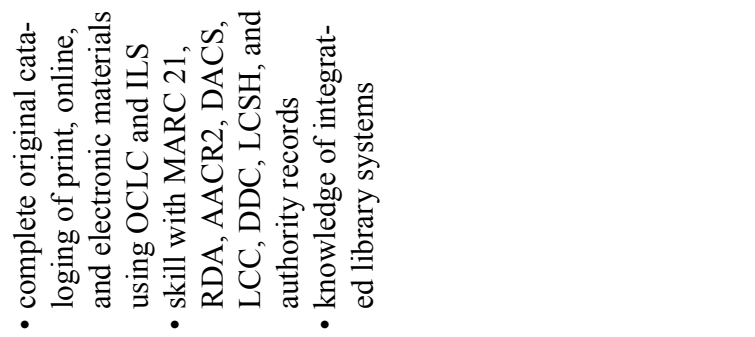 \\
\hline & 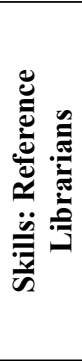 & 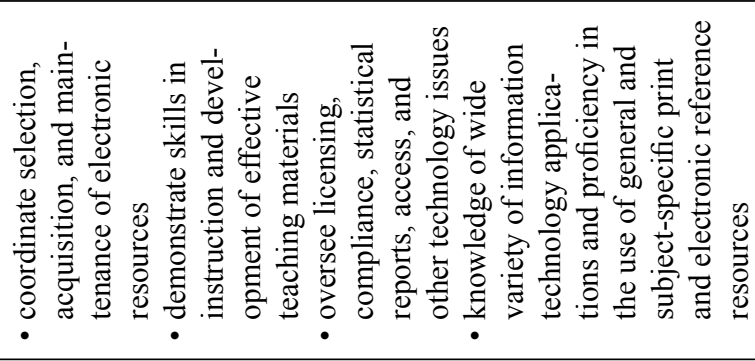 \\
\hline & 章 & 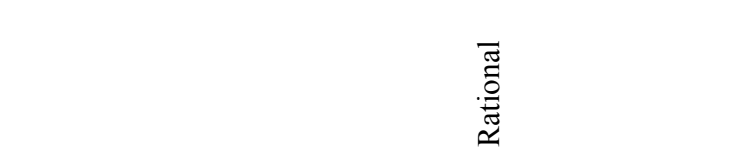 \\
\hline & 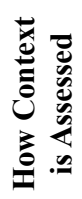 & 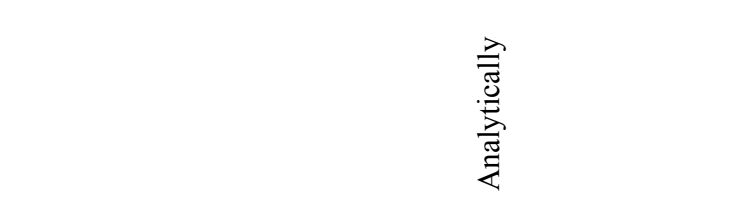 \\
\hline & 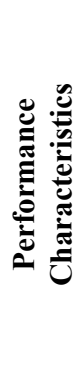 & 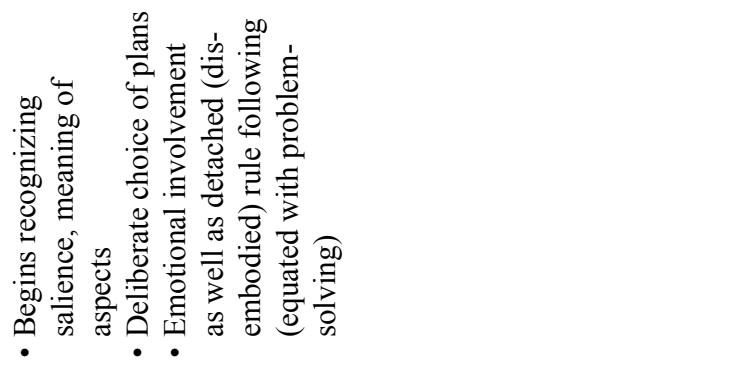 \\
\hline & 可 & $\stackrel{\dot{\Xi}}{\stackrel{\Xi}{0}}$ \\
\hline
\end{tabular}




\begin{tabular}{|c|c|c|c|}
\hline \multirow{7}{*}{ 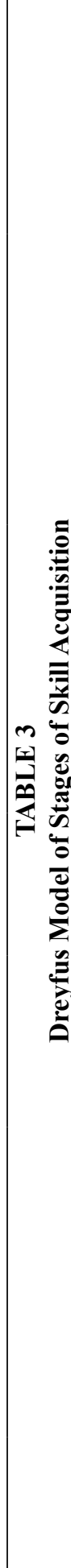 } & 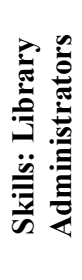 & 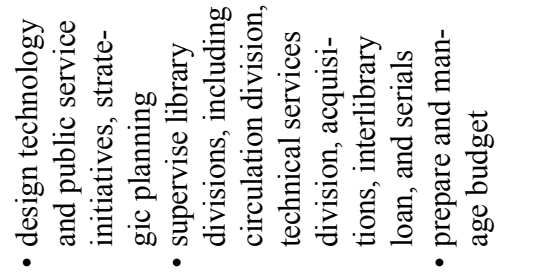 & 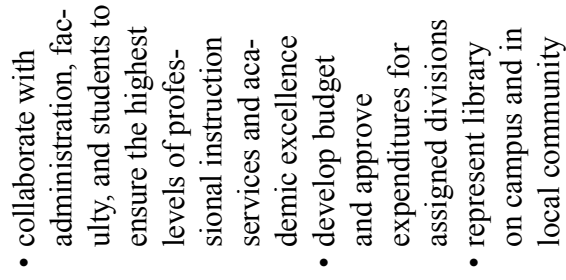 \\
\hline & 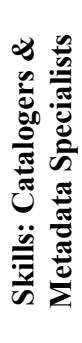 & 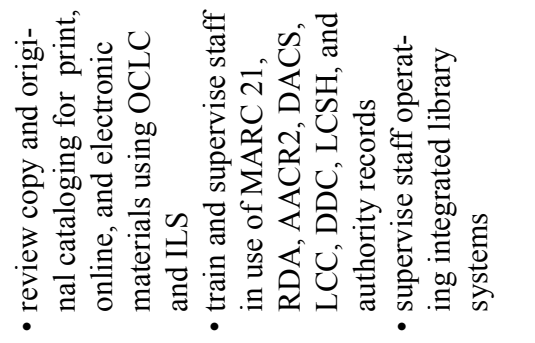 & 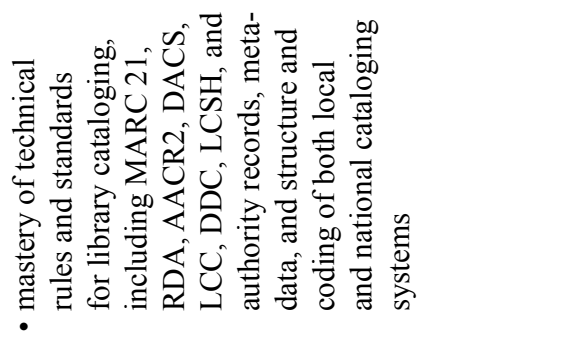 \\
\hline & 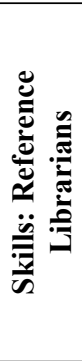 & 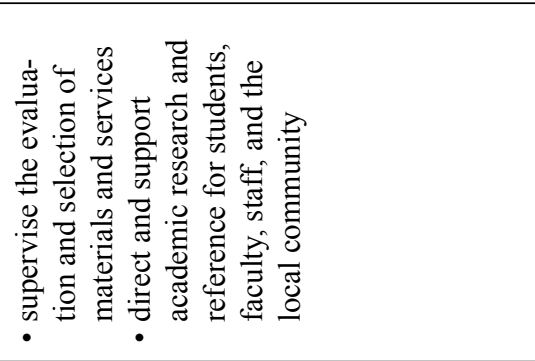 & 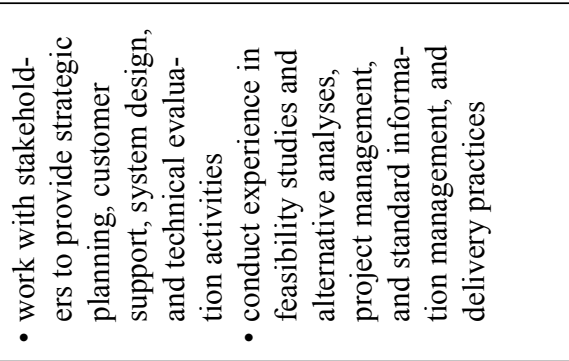 \\
\hline & 音 & 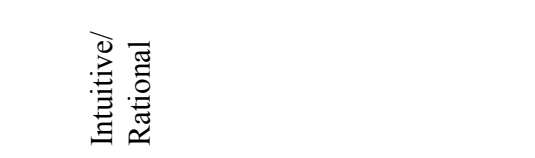 & 总䒿 \\
\hline & 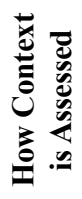 & 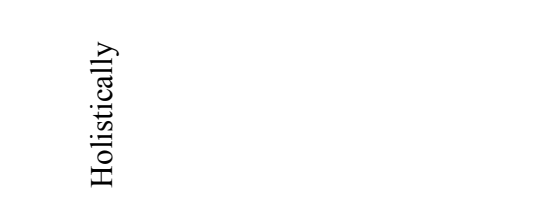 & \\
\hline & 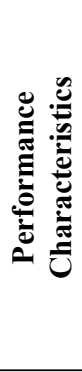 & 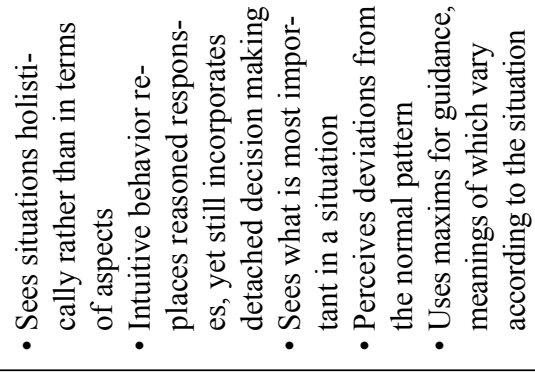 & 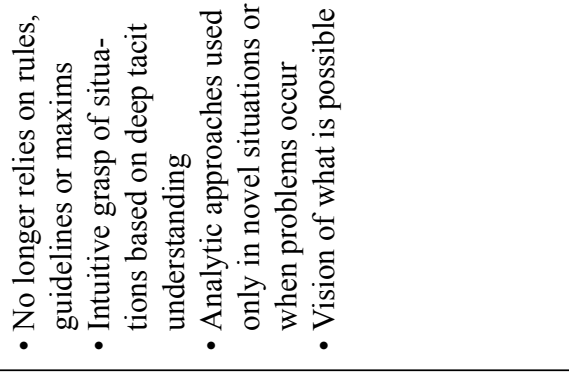 \\
\hline & 雲 & $\begin{array}{l}\overrightarrow{0} \\
\frac{0}{0} \\
0 \\
0 \\
0 \\
0\end{array}$ & 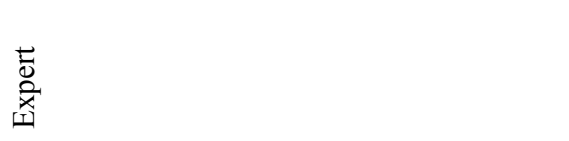 \\
\hline
\end{tabular}




\section{Notes}

1. William J. Rothwell, Effective Succession Planning: Ensuring Leadership Continuity and Building Talent from Within, 4th ed. (New York: AMACOM, 2010), 6-9.

2. Paul S. Ostrowski, "Prerequisites for Effective Succession Planning," Management of Personnel Quarterly 7, no. 1 (Spring 1968): 10-16.

3. Walter R. Mahler and William F. Wrightnour, Executive Continuity: How to Build and Retain an Effective Management Team (Homewood, Ill.: Dow Jones-Irwin, 1973).

4. Emily Osbun Bermes, "Succession Planning for the Small Business," Business People (Feb. 2011): 60; Susanne Driscoll, "How to Plan for Succession," Commercial Carrier Journal 168, no. 3 (Mar. 2011): 130-31; William J. Rothwell, "Replacement Planning: A Starting Point for Succession Planning and Talent Management," International Journal of Training and Development 15, no. 1 (2011): 87-99.

5. Elizabeth Blakesley, "Planning for the Future: Sources to Explore about Succession Planning," Library Leadership E Management 25, no. 2 (May 2011): 1-4.

6. Judith M. Nixon, "Growing Your Own Leaders: Succession Planning in Libraries," Journal of Business \& Finance Librarianship 13, no. 3 (2008): 249-60.

7. Duane E. Webster and DeEtta Jones Young, "Our Collective Wisdom: Succession Planning and the ARL Research Library Leadership Fellows Program," Journal of Library Administration 49, no. 8 (2009): 781-93.

8. Helen Fallon, Jane Maxwell, Ciara McCaffrey, and Seamus McMahon, "Engaging with Leadership Development in Irish Academic Libraries: Some Reflections of the Future Leaders Program (FLP)," Australian Library Journal 60, no. 1 (Feb. 2011): 8-20; Angela Bridgland, "To Fill, or How to Fill-That Is the Question: Succession Planning and Leadership Development in Academic Libraries," Australian Academic E Research Libraries 30, no. 1 (Mar. 1999): 20-29.

9. Hubert L. Dreyfus and Stuart E. Dreyfus with Tom Anthansiou, Mind Over Machine: The Power of Human Intuition and Expertise in the Era of the Computer (New York: Free Press, 1986), xii.

10. Ibid., 20.

11. Stuart E. Dreyfus and Hubert L. Dreyfus, A Five-Stage Model of the Mental Activities Involved in Directed Skill Acquisition, Storming Media, available online at www.stormingmedia.us/15/1554/ A155480.html [accessed 15 April 2012].

12. Chris Argyris and Donald A. Schön. Theory in Practice: Increasing Professional Effectiveness (San Francisco: Jossey-Bass, 1974); Mark K. Smith, “Donald Schön: Learning, Reflection and Change," The Encyclopedia of Informal Education, 2001, 2011, available online at www.infed.org/ thinkers/et-schon.htm [accessed 25 April 2012]; Denise Anthony, Beyond Description: An Exploration of Experienced Archivists' Knowledge and Searching Skills (unpublished dissertation,. Ann Arbor: University of Michigan, 2006).

13. Dreyfus and Dreyfus, A Five-Stage Model, 21.

14. Dreyfus and Dreyfus, A Five-Stage Model, 31.

15. Patricia E. Benner, From Novice to Expert: Excellence and Power in Clinical Nursing Practice (Menlo Park, Calif.: Addison-Wesley Publishing Co., Nursing Division, 1984), 4.

16. Benner, From Novice to Expert, ix.

17. Benner, From Novice to Expert, vi, viii.

18. Kari Kuutti, "Activity Theory as a Potential Framework for Human-Computer Interaction Research," in Context and Consciousness: Activity Theory and Human-Computer Interaction, ed. Bonnie A. Nardi (Cambridge, Mass.: MIT Press, 1996), 28.

19. Etienne C. Wenger and William M. Snyder. "Communities of Practice: The Organizational Frontier," in Organizational Learning (Cambridge, Mass.: Harvard Business School Press, 2001), $1-20$.

20. William Sullivan, "Preparing Professionals as Moral Agents," in Carnegie Perspectives: Carnegie Foundation for the Advancement of Teaching, available online at www.carnegiefoundation. org/perspectives/preparing-professionals-moral-agents [accessed 15 April 2012].

21. Bonnie A. Nardi and Vickie O'Day, "Intelligent Agents: What We Learned at the Library," Libri 46, no. 2 (1996): 59.

22. Bonnie A. Nardi, "Activity Theory and Human-Computer Interaction," in Context and Consciousness: Activity Theory and Human-Computer Interaction, ed. Bonnie A. Nardi (Cambridge, Mass.: MIT Press, 1996), 7.

23. Nardi and O'Day, "Intelligent Agents: What We Learned at the Library," 70.

24. Bonnie A. Nardi and Vickie O'Day, "Application and Implications of Agent Technology for Libraries," Electronic Library 16, no. 5 (1998): 333.

25. Nardi and O'Day, "Intelligent Agents: What We Learned at the Library," 61.

26. Congress on Professional Education: Focus on Education for the First Professional Degree (Chicago, 
Ill.: American Library Association, 2005).

27. Susan Jurow, "Core Competencies: Strategic Thinking about the Work We Choose to Do," Journal of Academic Librarianship 22, no. 4 (July 1996): 301.

28. Dorothy Leonard-Barton, Wellsprings of Knowledge: Building and Sustaining the Sources of Innovation (Cambridge, Mass.: Harvard Business School Press, 1995), 4.

29. Competencies for Information Professionals of the 21st Century, rev. ed. June 2003, available online at www.sla.org/content/learn/members/competencies/index.cfm [accessed 15 April 2012].

30. Deborah S. Grealy, "Special Librarians Set New Standard for Academe," Information Outlook 2, no. 8 (Aug. 1998): 17-22.

31. June Lester and Connie Van Fleet, "Use of Professional Competencies and Standards Documents for Curriculum Planning in Schools of Library and Information Studies Education," Journal of Education for Library and Information Science 49, no. 1 (Winter 2008): 43-69.

32. Sandy Hirsh, "Preparing Future Professionals through Broad Competency Planning," Information Outlook 12, no. 1 (Jan./Feb. 2012): 9-11.

33. María E. González, "Workforce Competencies: Focus on Urban Public Libraries," Library Trends 59, nos. 1/2 (Summer/Fall 2010): 269-87.

34. Shorette Ammons-Stephens, Holly J. Cole, Keisha Jenkins-Gibbs, Catherine Fraser Riehle, and William H. Weare, "Developing Core Leadership Competencies for the Library Profession," Library Leadership \& Management 23, no. 2 (2009): 63-74.

35. Peter M. Senge, The Fifth Discipline: The Art and Practice of the Learning Organization (New York: Currency Doubleday, 1990); Peter F. Drucker, "Coming of the New Organization," in Harvard Business Review on Knowledge Management (Boston: Harvard Business School Press, 1998), 1-29; James R. Davis and Adelaide B. Davis, Effective Training Strategies: A Comprehensive Guide to Maximizing Learning in Organizations (San Francisco: Berrett-Koehler Publishers, 1998), 25.

36. Deborah S. Grealy, Lois M. Jones, and Kostas G. Messas, "Staff Development and Training in College and University Libraries: The Penrose Perspective," Library Administration E Management 10, no. 4 (Fall 1996): 204.

37. The Involved Academic Library Administrator, available online at http://acrlog.org/2009/09/24/ the-involved-academic-library-administrator/ [accessed 15 April 2012]; Miriam A. Drake, "Academic Libraries Are Alive and Thriving: Interviews with Four Academic Library Directors," Searcher 15, no. 1 (Jan. 2007): 8-12.

38. Deborah S. Grealy and Sylvia D. Hall-Ellis, From Research to Practice: The Scholarship of Teaching and Learning in LIS Education (Westport, Conn.: Libraries Unlimited, 2009).

39. Malcolm S. Knowles, The Modern Practice of Adult Education (Chicago: Follett Publishing Company, 1980), 41.

40. Sharan Merriam and Rosemary Caffarella, Learning in Adulthood: A Comprehensive Guide (San Francisco: Jossey-Bass, 1991).

41. Arthur Chickering and Robert Havinghurst, The Modern American College (San Francisco: Jossey-Bass, 1981).

42. Malcolm S. Knowles, Self-Directed Learning: A Guide for Learners and Teachers (Englewood Cliffs, N.J.: Prentice Hall, 1975).

43. Kimberly A. Neuendorf, The Content Analysis Guidebook (Thousand Oaks, Calif.: Sage Publications, 2002), 53-54.

44. Neuendorf, The Content Analysis Guidebook, 10.

45. Irving L. Janis, "The Problem of Validating Content Analysis," in Language of Politics: Studies in Quantitative Semantics, eds. Harold D. Lasswell, Nathan Leites and Associates (New York: George W. Stewart, 1949), 55-82.

46. S.S. Stevens, "Mathematics, Measurement, and Psychophysics," in Handbook Experimental Psychology, ed. S.S. Stevens (New York: Wiley, 1951), 1-49.

47. Ole R. Holsti, Content Analysis for the Social Sciences (Reading, Mass.: Addison-Wesley, 1969). 


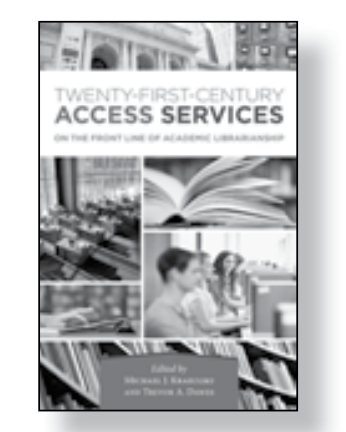

\section{Twenty-First-Century Access Services: On the} Front Line of Academic Librarianship

Edited by Michael J. Krasulski, Jr. and Trevor A. Dawes ISBN: 978-0-8389-8666-0

The ten chapters in this volume highlight the expanded roles of access services departments and discuss the role these services will continue to play in the success of the library. It also places these services in the context of supporting the academic mission of institutions and their libraries. Useful to access services practitioners in all types of academic libraries, and to library and information science graduate students and faculty.

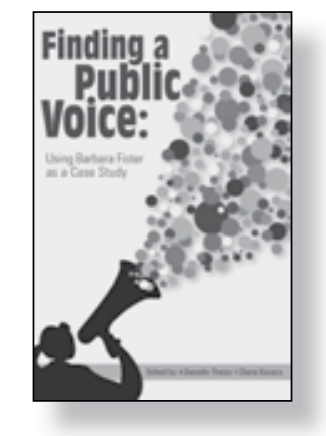

\section{Finding a Public Voice: Barbara Fister as a}

\section{Case Study}

Edited by Danielle Theiss and Diane Kovacs

ISBN: 978-0-8389-8652-3

This eclectic volume shares vivid examples of how academic librarians, inspired by the writings of noted library leader and blogger Barbara Fister, are engaging with others and blazing a leadership path for the profession on topics such as information literacy, scholarly communication and e-publishing, librarian career adaptability and healthcare privacy rights. Essential reading for librarians interested in information literacy, scholarly communication, e-publishing and the future of the profession.

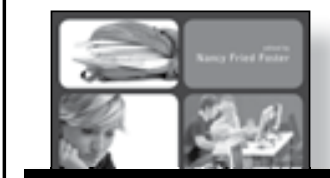

\section{FORTHCOMING!}

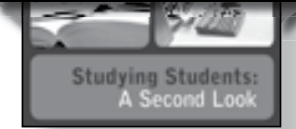

\section{Studying Students: A Second Look}

Edited by Nancy Fried Foster

ISBN: 978-0-8389-8680-6

Look for ACRL's forthcoming sequel to the best-selling Studying Students: The Undergraduate Research Project at the University of Rochester. The follow-up, Studying Students: A Second Look, reports on the new study done almost ten years after the first, drawing comparisons to the original work and developing new topics that have evolved since 2004 and 2005.

Available from the ALA online store:

\section{http://www.alastore.ala.org/}

